\title{
The Microbial Efficiency-Matrix Stabilization (MEMS) framework integrates plant litter decomposition with soil organic matter stabilization: do labile plant inputs form stable soil organic matter?
}

\author{
M. FRANCESCA COTRUFO*†, MATTHEW D. WALLENSTEIN $\uparrow$, CLAUDIA M. BOOT $\uparrow$, \\ KAROLIEN DENEF† and ELDOR PAUL $\dagger$ \\ *Department of Soil and Crop Sciences, Colorado State University, 200 W. Lake st., Fort Collins, CO 80523, USA, †Natural \\ Resource Ecology Laboratory, Colorado State University, 200 W. Lake st., Fort Collins, CO 80523, USA
}

\begin{abstract}
The decomposition and transformation of above- and below-ground plant detritus (litter) is the main process by which soil organic matter (SOM) is formed. Yet, research on litter decay and SOM formation has been largely uncoupled, failing to provide an effective nexus between these two fundamental processes for carbon (C) and nitrogen (N) cycling and storage. We present the current understanding of the importance of microbial substrate use efficiency and $\mathrm{C}$ and $\mathrm{N}$ allocation in controlling the proportion of plant-derived $\mathrm{C}$ and $\mathrm{N}$ that is incorporated into SOM, and of soil matrix interactions in controlling SOM stabilization. We synthesize this understanding into the Microbial Efficiency-Matrix Stabilization (MEMS) framework. This framework leads to the hypothesis that labile plant constituents are the dominant source of microbial products, relative to input rates, because they are utilized more efficiently by microbes. These microbial products of decomposition would thus become the main precursors of stable SOM by promoting aggregation and through strong chemical bonding to the mineral soil matrix.
\end{abstract}

Keywords: litter decomposition, litter quality, soil organic matter, microbial substrate use efficiency, humification, soil matrix protection

Received 21 November 2012 and accepted 25 November 2012

\section{Introduction}

While much is known about how climate, litter quality, and decomposer community composition affect the rate of plant litter decomposition, little is known about the factors that control the proportion of litter $\mathrm{C}$ and $\mathrm{N}$ that is eventually incorporated into stable SOM (Prescott, 2010). This stable fraction is a critical determinant of long-term net ecosystem $\mathrm{C}$ and $\mathrm{N}$ balances from the perspective of $C$ sequestration and reactive $\mathrm{N}$ dynamics.

Above- and below-ground plant litter decomposition studies have traditionally focused on decay rates and mass loss dynamics. The guiding paradigm has been that litter mass loss - commonly measured using mesh bags - represents losses from the system, while the amount of litter which does not decompose at a measureable rate contributes to stable SOM (humus) formation (Berg \& McClaugherty, 2008). This view does not account for leaf, root, or wood litter-derived OM

Correspondence: M. Francesca Cotrufo, tel. +1 970491 6056, fax +1 970491 1965, e-mail: Francesca.cotrufo@colostate.edu incorporation in the mineral soil through: (1) leaching of soluble plant and microbial compounds (i.e., dissolved organic matter: DOM), and (2) incorporation of litter fragments into soil aggregates (Cotrufo et al., 2009).

Soil organic matter is formed through the partial decomposition of plant debris by microorganisms (Paul, 2007). Historically, the formation of SOM or 'humification' has been studied separately from litter decomposition by analyzing SOM chemical structural changes in soil profiles (Zech \& Kogel-Knabner, 1994). Soil scientists have proposed two general humification schemes: biopolymer degradation and abiotic condensation (Frimmel \& Christman, 1988). The degradation models assume selective preservation of recalcitrant plant and microbial macromolecules, as humus, and mineralization of labile components. By contrast, the condensation models propose that low molecular weight (LMW) substances, derived from the biological degradation of plant and microbial residues, abiotically condense into polymers, forming humus.

Recent studies have greatly advanced our understanding of plant litter decomposition, SOM formation, and the chemical composition of stable soil $\mathrm{C}$ and $\mathrm{N}$ 
forms (Sollins et al., 2007; Kleber, 2010). By following the decomposition of isotopically enriched litter, it has become clear that early-stage leaf and root litter decomposition products contribute a relatively large amount of $C$ to the mineral soil (Bird et al., 2008; Rubino et al., 2010) and that this contribution is primarily from microbial compounds produced during the degradation of litter (Mambelli et al., 2011), while recalcitrant plant components do not preferentially accumulate in SOM (Marschner et al., 2008). The importance of microbial residues to the formation of stable SOM has been recognized for over a decade (e.g., Huang et al., 1998; Gleixner et al., 1999) and demonstrated through various experimental observations, including low $\mathrm{C}: \mathrm{N}$ ratios, low amounts of recalcitrant plant compounds (e.g, lignin and phenols), and high amounts of microbial biomass and microbial-derived compounds (e.g., carbohydrates, lipids, and peptides) in older SOM fractions (Sollins et al., 2009; Mambelli et al., 2011), as well as the somewhat similar chemical composition of microbial biomass and SOM (Simpson et al., 2007; Miltner et al., 2009). These results, along with the observed similarity in chemical composition of SOM across a variety of ecosystems (Grandy \& Neff, 2008) suggest a universal mechanism of SOM formation.

Some SOM scientists have recently disputed the theory of humus formation via transformation and condensation processes of plant structural compounds, to embrace the hypothesis of 'de novo formation of humic polymers' through microbial synthesis and stabilization by the soil matrix (Schmidt et al., 2011). Current evidence suggests that these humic substances are a complex mixture of microbial and plant polymers and their degradation products associated in super structures stabilized by hydrogen and hydrophobic bonds.

This wealth of disjointed information requires a conceptual framework that advances our understanding of the nexus between plant litter decomposition and SOM formation and leads to improved models of $C$ and $\mathrm{N}$ cycling in terrestrial ecosystems, with the ultimate goal of more accurate predictions of carbon-climate feedbacks.

\section{The Microbial Efficiency-Matrix Stabilization (MEMS) framework to integrate plant litter decomposition and SOM stabilization}

A growing body of evidence demonstrates that microbial products are the largest contributor to stable SOM (Knicker, 2011) and that the quantity and strength of organo-mineral bonds are the major control on longterm SOM stabilization (Kogel-Knabner et al., 2008). This understanding can be synthesized by the following postulates:
(1) A 'microbial filter' (sensu Wickland et al., 2007) controls the flow of $\mathrm{C}$ and $\mathrm{N}$ from plant litter to SOM: the efficiency with which plant substrates are incorporated into microbial biomass and allocated to different byproducts (e.g., enzymes, polysaccharides) vs. being mineralized is the prime determinant of plant-derived $\mathrm{C}$ and $\mathrm{N}$ contribution to SOM formation. Thus, all the factors that affect microbial substrate use efficiency and $\mathrm{C}$ and $\mathrm{N}$ allocation, such as substrate quality and quantity, climate, $\mathrm{pH}$, and $\mathrm{N}$ levels, are critical modifiers of litter decomposition and SOM formation. In this article, we limit our discussion to the role of plant litter quality, but acknowledge that any of the other factors may be equally or even more important (Allison et al., 2010; Manzoni et al., 2012; Schimel \& Schaeffer, 2012).

(2) Interactions of SOM with the mineral soil matrix are the ultimate controller of OM stabilization in soils over decadal to millennial time-scales. These interactions vary with the composition of both reactants (Kogel-Knabner et al., 2008). With respect to the soil matrix, the major features controlling OM stabilization are: (i) expandable and nonexpandable phyllosilicates; (ii) $\mathrm{Fe}-$, Al-, Mn-oxides; (iii) polyvalent cations (especially $\mathrm{Ca}^{2+}$ ) that can form bridges between largely negatively charged SOM and negatively charged phyllosilicates; and (iv) where they do occur, the short order silicates such as allophane (von Lutzow et al., 2006; Dumig et al., 2012; Mikutta \& Kaiser, 2011).

These two established concepts can be unified into what we call the Microbial Efficiency-Matrix Stabilization (MEMS) framework. The MEMS framework represents the decomposition, transformation, and stabilization of $\mathrm{OM}$ as a continuum, with microbial substrate use efficiency and $\mathrm{C}$ and $\mathrm{N}$ allocation and soil matrix interactions being the two key processes that control the fate of litter inputs to soils. This framework leads to the hypothesis that labile plant constituents are the dominant source of microbial products, relative to input rates, because they are utilized more efficiently by microbes. These microbial products of decomposition would thus become the main precursors of stable SOM by promoting aggregation and through strong chemical bonding to the mineral soil matrix (Fig. 1).

Specific decomposition and SOM formation pathways evolve as ecosystem properties (Schmidt et al., 2011). We argue that these pathways will inevitably result in OM from litter detritus going through microbial transformations and soil matrix interactions, before being stabilized over the long-term, with the exception of SOM stabilization due to inhibition of microbial activity (sensu Trumbore (2009). 

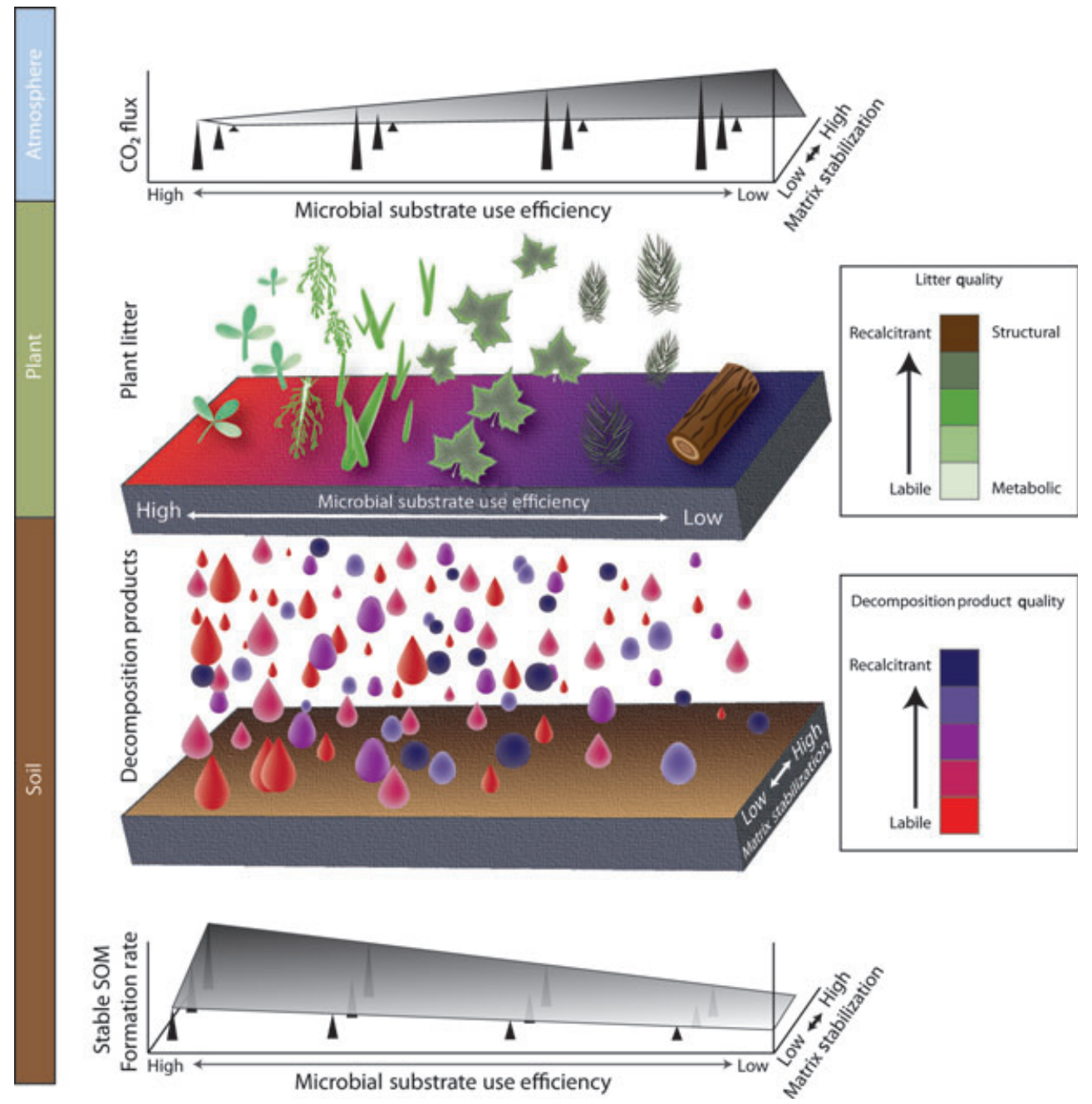

Fig. 1 Representation of the effects of plant litter quality on $\mathrm{CO}_{2}$ efflux and soil organic matter stabilization in the Microbial EfficiencyMatrix Stabilization (MEMS) framework. During decomposition, above- and below-ground plant litters undergo microbial processing which determines the quantity and chemical nature of decomposition products. Proportionally more dissolved organic matter and more carbohydrates and peptides are formed from high-quality (e.g., fine roots and herbaceous) litter than low-quality (e.g., needle and wood) litter, which loses most of the $\mathrm{C}$ as $\mathrm{CO}_{2}$. The ultimate fate of the decomposition products depends on their interactions with the soil matrix. Proportionally more stable soil organic matter (SOM) accumulates in soils with a high soil matrix stabilization (e.g., high expandable and nonexpandable phyllosilicates; high Fe-, Al-, Mn-oxides in acidic soils or polyvalent cations in alkaline soils, and high allophane content, where they do occur).

\section{Microbial substrate use efficiency and allocation}

Substrate use efficiency (SUE), the proportion of assimilated substrates that is used for growth and enzyme production vs. being mineralized or respired, is a function of both substrate quality (e.g., molecular weight, solubility, structural complexity, $\mathrm{C}: \mathrm{N})$ and degradative efficacy of microbes (Lekkerkerk et al., 1990), which can vary with microbial community composition, such as the fungi-to-bacteria ratio (Six et al., 2006) and with other environmental factors (Manzoni et al., 2012). More specifically, SUE is a measure of the amount of
ATP released through catabolism vs. the production of biomolecules through anabolic processes, which is controlled by a combination of the stoichiometry, oxidation state, and other aspects of substrates and the physiological state of microbial cells. The amount of energy required for maintenance can vary with $\mathrm{pH}$, osmotic potential, and microclimate of the soil environment (Vallino et al., 1996; del Giorgio \& Cole, 1998). Higher SUE's have been reported for simple metabolic compounds (as high as 73\% for glucose (Dijkstra et al., 2011)) compared with complex structural plant components (as low as $8-31 \%$ for lignin (Bahri et al., 2008)). 
Protected polymers such as lignin-encrusted cellulose must first be depolymerized by extracellular enzymes prior to assimilation. This incurs an extra cost to microbes, and thus a reduction in SUE (but most analytical approaches for measuring SUE do not account for this cost). For plant litter, SUE decreases with increasing lignin concentration (Lekkerkerk et al., 1990). Thus, a higher proportion of the mass contained in labile substrates is allocated toward microbial biomass and products compared with more complex substrates that have high energy cost associated with breakdown.

Besides SUE, the allocation of plant-derived OM into different microbial products and their persistence is critical to SOM formation. The impact of substrate quality on the formation and turnover of microbial products has been investigated following a microbial OM proxy, such as amino sugars. These components of microbial cell walls tend to form rapidly and accumulate in SOM in the presence of substrates richer in $\mathrm{N}$ (Liang et al., 2007), suggesting that the substrate quality is a determining factor affecting microbial residue accumulation.

The contribution of microbial metabolites, such as enzymes, to SOM formation requires a closer look at the mechanisms underlying the production and activity of extracellular enzymes and the importance of biotic and abiotic factors in regulating enzyme stability. Once produced and released by microbes, enzymes may be freely dissolved in the soil solution or bound to microbes, SOM or minerals. Conditions that lead to increased organo-mineral interactions (e.g., finer soil texture, presence of noncrystalline minerals) are generally found to decelerate enzyme degradation (Allison, 2006), yet the consequences for enzyme function are less clear as assay-based measurements of increased enzyme activity do not necessarily correspond to rapid C turnover under field conditions (Steinweg et al., 2012). This disconnect may be attributed to our inability to detect enzyme activity in situ (Wallenstein \& Weintraub, 2008). Enhanced SOM accumulation under enzyme-stabilizing conditions may therefore be linked to increasing physical isolation of enzymes and substrates (Rillig et al., 2007).

\section{Soil matrix interactions}

Once substrate $\mathrm{C}$ and $\mathrm{N}$ are assimilated into microbial biomass and products, their ultimate fate is determined by the interaction with the soil matrix (Six et al., 2006). Soil organic matter is protected from decomposition through a combination of chemical and physical mechanisms, a topic that has been thoroughly reviewed in the literature (e.g., Dungait et al., 2012). Chemically, SOM can have inherent recalcitrance based on its functional group (e.g., alkyl, amide, aromatic) composition and molecular structure. Physically, SOM can be protected by being spatially inaccessible to microbes (e.g., aggregate occlusion, hydrophobic encapsulation). A third protection mechanism integrates physical (spatial proximity) and chemical (solubility, charge, molecular weight, and polymeric state) characteristics of organic and mineral components, which we refer to as 'matrix stabilization' (e.g., ligand exchange, hydrogen bonding) and is controlled by the amount and quality of silt and clay particles (Sorensen, 1981; Sollins et al., 1996; von Lutzow et al., 2006). The expandable and non expandable phyllosilicates drive many of the OM-matrix interactions. The Fe-, Al-, Mn-oxides, which often occur as clay coatings, interact through large surface areas, micropores, and microaggregation, especially in acidic soils. In neutral and calcareous soils, by contrast, polyvalent cations (especially $\mathrm{Ca}^{2+}$ ) predominate and form bridges between the largely negatively charged SOM and negatively charged phyllosilicates. Finally, the short order silicates such as allophane provide some of the strongest organo-mineral interactions and have been shown to stabilize carbohydrate monomers as well as proteins, yet are much more geographically restricted (Buurman et al., 2007; Dumig et al., 2012; Mikutta \& Kaiser, 2011). Chemical recalcitrance and spatial inaccessibility operate over the short-to-medium term (e.g., decades), whereas matrix stabilization controls SOM persistence over the longterm (e.g., centuries) (Kogel-Knabner et al., 2008).

These chemical and physical mechanisms operate regardless of whether residues are of microbial or plant origin (Spence et al., 2011). Plants introduce OM belowground as both LMW compounds (e.g., oxalate, citrate, phenols) from root exudates and litter leachates, and high molecular weight polymeric (HMW) material (e.g., cellulose, lignin, suberin, cutin) through root sloughing and litter fragments input. Similarly, microorganisms also provide LMW cytoplasmic constituents as well as polymeric HMW cell membranes (Nelson et al., 1979).

While the stabilization mechanisms operate regardless of OM origin, SOM stabilization can be indirectly promoted by microbial processing of plant material, through the beneficial effect of microbes on aggregate formation and subsequent effects on organo-mineral stabilization. Microbial-derived SOM is generally greater in clay fractions (Clemente et al., 2011) and the concentration of microbial cell wall components correlate with stable aggregate formation in clay soils (Guggenberger et al., 1999). Microbial decomposition is thus important for the degradation and transformation of plant detritus into microbial products as well as the stabilization of these products in SOM. 


\section{From plant litter decomposition to SOM stabilization: the role of litter quality}

Plant litter quality is a primary controller of litter decomposition rates, with faster decay associated with lower concentrations of chemically recalcitrant substrates (Zhang et al., 2008). Yet, recalcitrant litter compounds do not preferentially stabilize in SOM (Marschner et al., 2008). What is, then, the nexus between litter decay and stable SOM formation? We argue that this apparent paradox arises because litter decomposition and stable SOM formation have been studied independently, resulting in contrasting paradigms. The MEMS framework provides the missing link and a unifying perspective on the role of litter quality.

Plant litter quality is commonly defined by decomposability: 'high-quality' litter decomposes fast (i.e., is labile) while 'low-quality' litter decomposes slowly (i.e., is recalcitrant). The litter quality parameters that better explain decomposability are litter C chemistry (i.e., relative concentrations of water-solubles, cellulose, lignin, lipids, etc.) and N content (Prescott, 2010). Some models use chemistry-dependent indices, e.g., the lignin-to- $\mathrm{N}$ ratio, to predict litter decay, as in the case of the Century-DayCent model (Parton et al., 1994) which partitions litter residues between a fast decomposing (decay rate of $0.03-0.05$ day $^{-1}$ ) metabolic pool and a slow decomposing (decay rate of 0.01 day $^{-1}$ ) structural pool on the basis of a linear relationship between lignin-to-N and litter decay rate (Melillo et al., 1982). Other examples of chemistry-dependent definition of litter quality include the decision trees proposed by Palm et al.(2001) to assess the suitability of litter for different management strategies in agricultural ecosystems, on the basis of residue $\mathrm{N}$ (break point at 2.5\%), phenols (break point at 4\%), and lignin (break point at $15 \%$ ) concentrations. Our discussion of the significance of litter quality is intended to stimulate further quantitative research that could lead to a chemistrydependent definition of litter quality.

It was previously assumed that the recalcitrant litter contributes more to SOM formation than labile litter because, by resisting degradation, it accumulates in soils. Given recent evidence overturning this paradigm, do the traditional metrics of litter quality still relate to their role in SOM formation?

\section{Carbon chemistry}

About half of plant litter mass is $\mathrm{C}$, which is present in numerous different chemical forms from soluble LMW compounds (e.g., sugars, amino acids, and phenols) to insoluble lipids, from simple (e.g., cellulose and proteins) to more complex polymers (e.g., lignin). These compounds differ in their size, structural complexity, and the type of chemical bonds. While the concentration of $\mathrm{C}$ does not change significantly among plant litters, the relative allocation of $\mathrm{C}$ to these different compounds does, and may control litter decay rates (Hattenschwiler \& Jorgensen, 2010). Typically, woody residues (i.e., coarse roots and wood) contain higher cellulose and lignin concentrations (cumulatively around 80-90\%) than leaves and herbaceous plant material, which contain as low as 3-14\% lignin (Aber \& Melillo, 1991). Needle litter is characterized by lower abundance (e.g., 9-18\%) of water-soluble constituents relative to broadleaf litter (e.g., 21-34\%) (Berg \& McClaugherty, 2008). The conventional model posits that the concentration of water-soluble and nonprotected cellulose is positively correlated with litter decay rates in the initial stages of litter decay, while the concentration of lignin is inversely related to decay rates during later stages of litter decomposition (Berg \& McClaugherty, 2008). In contrast, our hypothesis posits that $\mathrm{C}$ chemistry controls litter decay through its effect on microbial SUE. Low molecular weight compounds are degraded faster - causing labile litter to decay faster, but with a relatively higher accumulation of microbial products in the longer term. Low-quality litter will initially decompose slower, but less of the initial mass will be converted into microbial products. This view is consistent with the recent findings that lignin does not preferentially accumulate in decomposing litter (Preston et al., 2009), and that it does in fact decompose during the early stage of decomposition, when available high-quality $\mathrm{C}$ fosters its breakdown (Klotzbucher et al., 2011).

We believe that these contradictory views of the role of lignin in litter decay are the result of a methodological artifact. The 'lignin' of the conventional model is an operationally defined fraction of litter that is not degraded by strong acid treatment, as measured by the acid detergent fiber method (Van Soest, 1963). Prior to decomposition, this recalcitrant fraction is made of plant structural components (i.e., lignin). With decay, it may become dominated by HMW substances of microbial and plant origin, which may bind to metal cations (e.g., $\mathrm{Mg}^{2+}, \mathrm{Ca}^{2+}$ ) (Preston et al., 2009). The MEMS framework is consistent with this understanding of lignin decomposition, as the accumulation of microbial products and not the lignin would be responsible for the buildup of SOM resistance.

\section{Litter nitrogen}

Plant N concentration varies, with as little as $0.1-0.5 \%$ in heartwood and needle litter (Berg \& McClaugherty, 
2008), an average of $1.1 \%$ in fine roots (Gordon \& Jackson, 2000), a range of $1-3 \%$ in broadleaves and up to $3-5 \%$ in several legumes and annual crops. Yet, plant $\mathrm{N}$ content relative to $\mathrm{C}$ is one to two orders of magnitude lower than microbial biomass. Because of this different stoichiometry (Manzoni et al., 2008), microbes degrade plant litter with an initial higher $\mathrm{N}$ concentration more quickly (Hobbie, 2005). In contrast, resistant $\mathrm{OM}$ residues tend to decompose faster when $\mathrm{N}$ limits microbial growth, and microbes need to mine $\mathrm{OM}$ richer in N (Craine et al., 2007). High $N$ levels (>1\%) generally speed up the initial stage of litter decomposition, dominated by the decay of labile litter components, but in the latter stages high-N litter decomposes slower and has more mass remaining than low-N litter (Fog, 1988). This dynamic can also be explained by the microbial use efficiency of plant detritus. In high-N litter, microbes are not $\mathrm{N}$-limited and initial decomposition proceeds faster. However, the substrate is also used with higher efficiency (Manzoni et al., 2010) resulting in greater accumulation of microbial products and concomitant stable SOM formation.

This mechanism would be particularly important in litter where high $\mathrm{N}$ is combined with high $\mathrm{C}$ quality (e.g., lignin $<15 \%$ ). This labile litter will initially decompose faster than recalcitrant litter (e.g., low $\mathrm{N}$ and $\mathrm{C}$ quality), but a higher fraction of the residue will accumulate over the longer term (Fig. 2).

Above-ground litter-derived SOM needs to move down to the mineral soil to stabilize. Few studies have quantified DOM leaching from litter and we lack an understanding of how it is related to litter quality (Kalbitz et al., 2000). We expect higher rates of DOM production from higher quality litters, consisting of both soluble plant- and microbial-derived compounds. Litter incorporation in the mineral soil also occurs through fragmentation and transfer of litter fragments

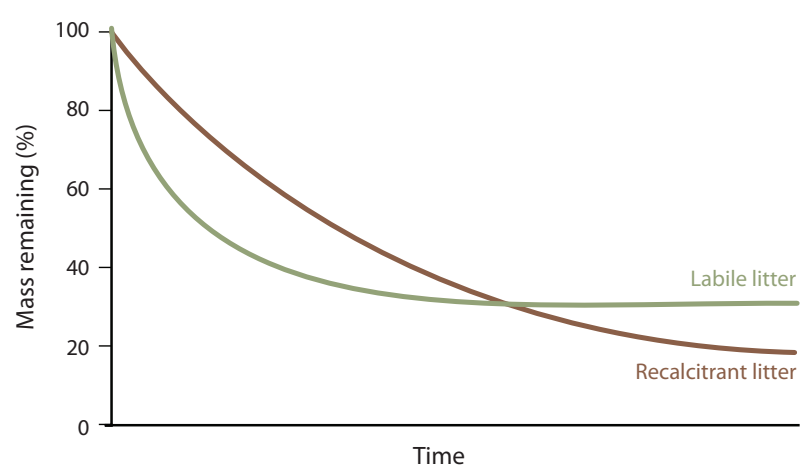

Fig. 2 Hypothetic dynamics of mass remaining during decomposition of a labile (i.e., high C quality and $\mathrm{N}$ concentration) and a recalcitrant (i.e., low $\mathrm{C}$ quality and $\mathrm{N}$ concentration) plant litter. at depth by fauna such as earthworms, which may be independent of litter quality (Fonte \& Six, 2010). In contrast with the above-ground plant tissues, roots senesce within the soil, thus root litter-derived OM may be more readily able to stabilize on soil minerals. Only a few studies have examined the stabilization of root vs. leaf litter derived $\mathrm{C}$ and $\mathrm{N}$ in SOM using isotopically labeled substrates (e.g., Bird et al., 2008; Kong \& Six, 2010; Mambelli et al., 2011). The generally relatively high $\mathrm{N}$ concentration of fine roots, their close proximity to the soil matrix and ability to stimulate physical stabilization (Denef \& Six, 2006) would support the claim that they are large contributors to stable SOM formation (Rasse et al., 2005).

After microbial processing, proportionally more SOM would be formed from high-quality litter compared with low-quality litter. But for this OM to be stabilized, it needs to be protected by the soil matrix. Given that the strongest form of matrix stabilization is bonding with minerals, and that microbial-derived compounds dominate in organo-mineral SOM fractions (Clemente et al., 2011; Dumig et al., 2012), more SOM should form and accumulate in the long-term from high-quality labile litter (Fig. 1).

The role of litter quality on stable SOM formation requires further testing; however, existing evidence appears to support our hypothesis. The strongest evidence comes from long-term studies of organic amendments: the use of legume (i.e., high quality) cover crops has generally resulted in the greatest increases in soil C among several other management practices, despite lower inputs as compared with cereals (Peters et al., 1997; Grandy \& Robertson, 2007). At the Ultuna continuous SOM field experiment, 42 years of manure addition (arguably the best example of a microbially processed substrate) increased the $\mathrm{C}$ content of the clay fraction by $287 \%$ with respect to the fallow control, whereas a smaller $155 \%$ increase resulted from peat additions, which instead accumulated $C$ in the coarser size fractions (Kirchmann et al., 2004). Experiments with isotopically labeled inputs also provide useful insights: In a field experiment where ${ }^{14} \mathrm{C}$-labeled glucose and wheat straw were added to soil, more ${ }^{14} \mathrm{C}$ was retained from the glucose than straw after 7 years (Voroney et al., 1989). Chronic amendment of dissolved ${ }^{13} \mathrm{C}$-labeled sugar resulted in 2.4 times greater soil C formation rates than for amino acid, with formation rates being positively correlated with the fraction recovered in the microbial biomass and negatively correlated with respiration rates (Bradford et al., in press). These examples provide field evidence for our hypothesis that labile plant components accumulate in high clay content soils through efficient use by soil microbes and stabilization by the soil matrix (Fig. 1). 


\section{Conclusions}

We invite soil scientists and ecologists to discuss the MEMS model as a unifying framework within which to incorporate their research on mechanisms controlling litter decomposition and SOM formation. These mechanisms are crucial for understanding long-term $\mathrm{C}$ and $\mathrm{N}$ cycling in terrestrial ecosystems, responses to land management and feedbacks to climate change. We suggest that the ability of soil biogeochemical models (e.g., Century-DayCent, Roth C, etc.) to predict long-term changes in soil $\mathrm{C}$ and $\mathrm{N}$ cycling would be improved by adopting the MEMS concepts. Rather than a fixed parameter, microbial SUE should be variable, modeled as a function of factors such as litter chemistry, climate, $\mathrm{pH}$, and microbial community composition. Soil matrix stabilization should be dependent on specific characteristics for different soil types such as the abundance of Fe-, Al-, Mn-oxides in acidic soils and cations in alkaline soils, or the allophane presence, rather than the currently used metric of percent clay. Finally, litter quality should be modeled using descriptive chemical structural data rather than operationally defined pools. However, these changes would add complexity to models, which can result in problems associated with overparameterization and would also require the collection of new data for parameterization and testing, in particular on the factors controlling microbial SUE and $\mathrm{C}$ and $\mathrm{N}$ allocation. We suggest that these are key determinants of soil $\mathrm{C}$ and $\mathrm{N}$ dynamics, and should be recognized as a critical research need.

\section{Acknowledgements}

We thank Drs. Josh Schimel and Keith Paustian for their insightful comments on this work. This work was supported by the National Science Foundation under Grants No. 1020540, 0918482, 0842315, 0840869, and 0816720.

\section{References}

Aber JD, Melillo J (1991) Terrestrial Ecosystems. Saunders College Publishing, Philadelphia.

Allison SD (2006) Soil minerals and humic acids alter enzyme stability: implications for ecosystem processes. Biogeochemistry, 81, 361-373.

Allison SD, Wallenstein MD, Bradford MA (2010) Soil-carbon response to warming dependent on microbial physiology. Nature Geoscience, 3, 336-340.

Bahri H, Rasse DP, Rumpel C, Dignac MF, Bardoux G, Mariotti A (2008) Lignin degradation during a laboratory incubation followed by (13)C isotope analysis. Soil Biology \& Biochemistry, 40, 1916-1922.

Berg B, McClaugherty C (eds.) (2008) Plant Litter. Decomposition, Humus Formation, Carbon Sequestration. Springer, Berlin.

Bird JA, Kleber M, Torn MS (2008) C-13 and N-15 stabilization dynamics in soil organic matter fractions during needle and fine root decomposition. Organic Geochemistry, 39, 465-477.

Bradford M, Kaiser AD, Davies CA, Mersmann CA, Strickland MS (in press) Empirical evidence that soil carbon formation from plant inputs is positively related to microbial growth. Biogeochemistry.
Buurman P, Peterse F, Almendros Martin G (2007) Soil organic matter chemistry in allophanic soils: a pyrolysis-GC/MS study of a Costa Rican Andosol catena. European Journal of Soil Science, 58, 1330-1347.

Clemente JS, Simpson AJ, Simpson MJ (2011) Association of specific organic compounds in size fractions of soils under different environmental controls. Organic Geochemistry, 42, 1169-1180.

Cotrufo MF, Del Galdo I, Piermatteo D (2009) Litter decomposition: concepts, methods and future perspectives. In: Soil Carbon Dynamics. An integrated methodology (eds Krutz W, Bahn M, Heinemeyr A), pp. 76-90. Cambridge University Press, Cambridge.

Craine JM, Morrow C, Fierer N (2007) Microbial nitrogen limitation increases decomposition. Ecology, 88, 2105-2113.

Denef K, Six J (2006) Contributions of incorporated residue and living roots to aggregate-associated and microbial carbon in two soils with different clay mineralogy. European Journal of Soil Science, 57, 774-786.

Dijkstra P, Thomas SC, Heinrich PL, Koch GW, Schwartz E, Hungate BA (2011) Effect of temperature on metabolic activity of intact microbial communities: evidence for altered metabolic pathway activity but not for increased maintenance respiration and reduced carbon use efficiency. Soil Biology \& Biochemistry, 43, 2023-2031.

Dumig A, Hausler W, Steffens M, Kögel Knaber I (2012) Clay fractions from a soil chronasequence after galciaer retreat reveal the initial evolution of organo mineral associations. Geochimica et Cosmochimica Acta, 85, 1-18.

Dungait JA, Hopkins DW, Gregory AS, Whitmore AP (2012) Soil organic matter turnover is governed by accessibility not recalcitrance. Global Change Biology, 18, $1781-1796$.

Fog K (1988) The effect of added nitrogen on the rate of decomposition of organic matter. Biological Review, 63, 433-462.

Fonte SJ, Six J (2010) Earthworms and litter management contributions to ecosystem services in a tropical agroforestry system. Ecological Applications, 20, 1061-1073.

Frimmel FH, Christman RF (eds.) (1988) Humic Substances and Their Role in the Environment. Wiley, Chichester.

del Giorgio PA, Cole JJ (1998) Bacterial growth efficiency in natural aquatic systems. Annual Review of Ecology and Systematics, 29, 503-541.

Gleixner G, Bol R, Balesdent J (1999) Molecular insight into soil carbon turnover. Rapid Communications in Mass Spectrometry, 13, 1278-1283.

Gordon WS, Jackson RB (2000) Nutrient concentrations in fine roots. Ecology, 81, 275-280.

Grandy AS, Neff JC (2008) Molecular C dynamics downstream: the biochemical decomposition sequence and its impact on soil organic matter structure and function. Science of the Total Environment, 404, 297-307.

Grandy AS, Robertson GP (2007) Land-use intensity effects on soil organic carbon accumulation rates and mechanisms. Ecosystems, 10, 58-73.

Guggenberger G, Frey SD, Six J, Paustian K, Elliott ET (1999) Bacterial and fungal cell-wall residues in conventional and no-tillage agroecosystems. Soil Science Society American Journal, 63, 1188-1198.

Hattenschwiler S, Jorgensen HB (2010) Carbon quality rather than stoichiometry controls litter decomposition in a tropical rain forest. Journal of Ecology, 98, 754-763.

Hobbie SE (2005) Contrasting effects of substrate and fertilizer nitrogen on the early stages of litter decomposition. Ecosystems, 8, 644-656.

Huang Y, Eglinton G, Van der Hage ERE, Boon JJ, Bol R, Ineson P (1998) Dissolved organic matter and its parent organic matter in grass upland soil horizons studied by analytical pyrolysis techniques. European Journal of Soil Science, 49, 1-15.

Kalbitz K, Solinger S, Park JH, Michalzik B, Matzner E (2000) Controls on the dynamics of dissolved organic matter in soils: a review. Soil Science, 165, 277-304.

Kirchmann H, Haberhauer G, Kandeler E, Sessitsch A, Gerzabek MH (2004) Effects of level and quality of organic matter input on carbon storage and biological activity in soil: synthesis of a long-term experiment. Global Biogeochemical Cycles, $18,9$.

Kleber M (2010) What is recalcitrant soil organic matter? Environmental Chemistry, 7, 320-332.

Klotzbucher T, Kaiser K, Guggenberger G, Gatzek C, Kalbitz K (2011) A new conceptual model for the fate of lignin in decomposing plant litter. Ecology, 92, 1052-1062.

Knicker H (2011) Soil oranic N - an under-rated player for C sequestration in soils? Soil Biology and Biochemistry, 43, 1118-1129.

Kogel-Knabner I, Guggenberger G, Kleber M et al. (2008) Organo-mineral associations in temperate soils: integrating biology, mineralogy, and organic matter chemistry. Journal of Plant Nutrition and Soil Science-Zeitschrift Fur Pflanzenernahrung Und Bodenkunde, 171, 61-82.

Kong AYY, Six J (2010) Tracing root vs. residue carbon into soils from conventional and alternative cropping systems. Soil Science Society of America Journal, 74, $1201-1210$. 
Lekkerkerk LJA, Lundkvist H, Agren G, Ekbohm G, Bosatta E (1990) Decomposition of heterogeneous substrates: an experimental investigation of a hypothesis on substrate and microbial properties. Soil Biology \& Biochemistry, 22, 161-167.

Liang C, Zhang XD, Rubert KF, Balser TC (2007) Effect of plant materials on microbial transformation of amino sugars in three soil microcosms. Biology and Fertility of Soils, 43, 631-639.

von Lutzow M, Kogel-Knabner I, Ekschmitt K, Matzner E, Guggenberger G, Marschner B, Flessa H (2006) Stabilization of organic matter in temperate soils: mechanisms and their relevance under different soil conditions - a review. European Journal of Soil Science, 57, 426-445.

Mambelli S, Bird JA, Gleixner G, Dawson TE, Torn MS (2011) Relative contribution of foliar and fine root pine litter to the molecular composition of soil organic matter after in situ degradation. Organic Geochemistry, 42, 1099-1108.

Manzoni S, Jackson RB, Trofymow JA, Porporato A (2008) The global stoichiometry of litter nitrogen mineralization. Science, 321, 684-686.

Manzoni S, Trofymow JA, Jackson RB, Porporato A (2010) Stoichiometric controls on carbon, nitrogen, and phosphorus dynamics in decomposing litter. Ecological Monographs, 80, 89-106.

Manzoni S, Taylor P, Richter A, Porporato A, Agren GI (2012) Environmental and stoichiometric controls on microbial carbon-use efficiency in soils. New Phytologist, 196, 79-91.

Marschner B, Brodowski S, Dreves A et al. (2008) How relevant is recalcitrance for the stabilization of organic matter in soils? Journal of Plant Nutrition and Soil Science-Zeitschrift Fur Pflanzenernahrung Und Bodenkunde, 171, 91-110.

Melillo JM, Aber JD, Muratore JF (1982) Nitrogen and lignin control of hardwood leaf litter decomposition dynamics. Ecology, 63, 621-626.

Mikutta R, Kaiser K (2011) Organic matter bound to mineral surfaces: resistance to chemical and biological oxidation. Soil Boil \& Biochemistry, 43, 1738-1741.

Miltner A, Kindler R, Knicker H, Richnow HH, Kastner M (2009) Fate of microbial biomass-derived amino acids in soil and their contribution to soil organic matter. Organic Geochemistry, 40, 978-985.

Nelson DW, Martin JP, Ervin JO (1979) Decomposition of microbial cells and components in soil and their stabilization through complexing with model humic acidtype phenolic polymers. Soil Science Society American Journal, 43, 84-88.

Palm CA, Giller KE, Mafongoya PL, Swift MJ (2001) Management of organic matter in the tropics: translating theory into practice. Nutrient Cycling in Agroecosystems, 61, 63-75.

Parton WJ, Ojima DS, Cole CV, Schimel DS (1994) A general model for soil organic matter dynamics: sensitivity to litter chemistry, texture and management. In Quantitative modeling of soil forming processes Vol. Special Publication no. 39 (eds Bryant RB, Arnold RW), pp. 147-167. Soil Science Society of America, Madison, Wisconsin, USA.

Paul EA (2007) Soil Microbiology, Ecology and Biogeochemistry. Academic Press, San Diego, CA, USA.

Peters SE, Wander M, Sapirito LS, Harris GH, Friedman DB (1997) Management impacts on SOM and related soil properties in a long term farming systems trial in Pennsylvania. In: Soil Organic Matter in Temperate Agroecosytems (eds Paul EA, Elliott ET, Pautin KH, Cole CV), pp. 183-196. CRC Press, Boca Raton, FL.

Prescott C (2010) Litter decomposition: what controls it and how can we alter it to sequester more carbon in forest soils? Biogeochemistry, 101, 133-149.

Preston CM, Nault JR, Trofymow JA (2009) Chemical changes during 6 years of decomposition of 11 litters in some Canadian forest sites. Part 2. C-13 abundance, solid-state C-13 NMR spectroscopy and the meaning of "Lignin". Ecosystems, 12, 1078-1102.
Rasse DP, Rumpel C, Dignac MF (2005) Is soil carbon mostly root carbon? Mechanisms for a specific stabilisation Plant and Soil, 269, 341-356.

Rillig MC, Caldwell BA, Wosten HAB, Sollins P (2007) Role of proteins in soil carbon and nitrogen storage: controls on persistence. Biogeochemistry, 85, 25-44.

Rubino M, Dungait JAJ, Evershed RP et al. (2010) Carbon input belowground is the major C flux contributing to leaf litter mass loss: evidences from a (13)C labelledleaf litter experiment. Soil Biology \& Biochemistry, 42, 1009-1016.

Schimel JP, Schaeffer SM (2012) Microbial control over carbon cycling in soil. Frontiers in Microbiology, 3, 1-11, doi: 10.3389/fmicb.2012.00348

Schmidt MWI, Torn MS, Abiven S et al. (2011) Persistence of soil organic matter as an ecosystem property. Nature, 478, 49-56.

Simpson AJ, Simpson MJ, Smith E, Kelleher BP (2007) Microbially derived inputs to soil organic matter: are current estimates too low? Environmental Science \& Technol$o g y, 41,8070-8076$.

Six J, Frey SD, Thiet RK, Batten KM (2006) Bacterial and fungal contributions to carbon sequestration in agroecosystems. Soil Science Society of America Journal, 70, 555-569.

Sollins P, Homann P, Caldwell BA (1996) Stabilization and destabilization of soil organic matter: mechanisms and controls. Geoderma, 74, 65-105.

Sollins P, Swanston C, Kramer M (2007) Stabilization and destabilization of soil organic matter - a new focus. Biogeochemistry, 85, 1-7.

Sollins P, Kramer MG, Swanston Cet al. (2009) Sequential density fractionation across soils of contrasting mineralogy: evidence for both microbial- and mineralcontrolled soil organic matter stabilization. Biogeochemistry, 96, 209-231.

Sorensen LH (1981) Carbon-nitrogen relationships during the humification of cellulose in soils containing different amounts of clay. Soil Biology and Biochemistry, 13, 313-321

Spence A, Simpson AJ, McNally DJ et al. (2011) The degradation characteristics of microbial biomass in soil. Geochimica Et Cosmochimica Acta, 75, 2571-2581.

Steinweg JM, Dukes JS, Wallenstein MD (2012) Modeling the effects of temperature and moisture on soil enzyme activity: linking laboratory assays to continuous field data. Soil Biology and Biochemistry, 55, 85-92.

Trumbore S (2009) Radiocarbon and soil carbon dynamics. Annual Review of Earth and Planetary Sciences, 37, 47-66.

Vallino JJ, Hopkinson CS, Hobbie JE (1996) Modeling bacterial utilization of dissolved organic matter: optimization replaces Monod growth kinetics. Limnology and Oceanography, 41, 1591-1609.

Van Soest PJ (1963) Use of detergents in the analysis of fibrous feeds. II. A rapid method for the determination of fiber and lignin. Journal of the Association of Official Agricultural Chemists, 46, 829-835

Voroney RP, Paul EA, Anderson DW (1989) Decomposition of wheat straw and stabilization of microbial products. Canadian Journal of Soil Science, 69, 63-77.

Wallenstein MD, Weintraub MN (2008) Emerging tools for measuring and modeling the in situ activity of soil extracellular enzymes. Soil Biology \& Biochemistry, 40, 2098-2106.

Wickland KP, Neff JC, Aiken GR (2007) Dissolved organic carbon in Alaskan boreal forest: sources, chemical characteristics and biodegradability. Ecosystems, 10 1323-1340, doi: 10.1007/s10021-007-9101-4

Zech W, Kogel-Knabner I (1994) Patterns and regulation of organic matter transformation in soils: litter decomposition and humification. In: Flux Control in Biological Systems (ed Schulze ED), pp. 303-334. Academic Press, Inc., San Diego, CA.

Zhang DQ, Hui DF, Luo YQ, Zhou GY (2008) Rates of litter decomposition in terrestrial ecosystems: global patterns and controlling factors. Journal of Plant Ecology$U k, 1,85-93$ 